\title{
OBITUARIES
}

Obituaries should be submitted by email to Annabel Nicholson at annabel.nicholson@nature.com. All submitted obituaries should be 450 words maximum in length (apart from obituaries for past presidents of the BDA where the length should be 800 words).

Content of the obituary is down to the individual author, and the approval of the family should be given for the obituary prior to submission to the $B D J$.

\section{ROBIN M. DAVIES}

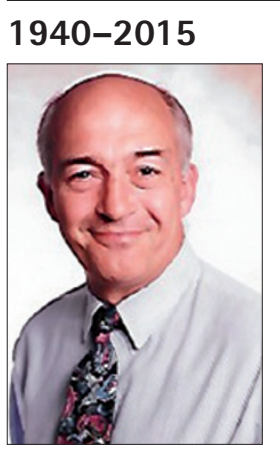

Robin Davies passed away after a short illness at Warrington General Hospital on the 5 April 2015, surrounded by his family. He was such a dynamic individual that any discussion of his talents could not do him justice. Robin was a fine athlete who had a trial for the Welsh rugby team, his research brain was incisive and his communication skills were legendary. He lectured all over the world to great acclaim. Although he was a gifted individual, his success was achieved through hard work and his need to strive for perfection in everything he did; thus he was at the vanguard of dental research focussing on scientific evidence. Graduating BDS from the University of Manchester in 1962, with a PhD in 1968, his scientific acumen was fostered when working with Professor Harold Loë at the University of Aarhus, who inspired his commitment to periodontal research. In 1971 he was appointed senior lecturer in periodontology at the University of Manchester. In 1977 he was head hunted by ICI to lead their dental research on two products, chlorhexidine oral rinses and composite restorative materials, both of which subsequently had lasting effects on dental clinical practice.

When ICI moved out of dental research in 1981 Robin moved to an academic post at the University of Bristol, but, looking for new challenges, moved in 1985 to the Armed Forces Hospital in Riyadh as a consultant in restorative dentistry. An excellent clinician and revered by his patients, his research and communication skills were such that in 1990 he was asked to head up the joint ColgateUniversity of Manchester collaboration, The Dental Health Unit, being appointed Professor and Director of Clinical Dental
Research, Europe. Once again he excelled and led the teams which provided the evidence for most of the benefits of Colgate Total. He also organised the only large scale RCT of a postal fluoride toothpaste distribution scheme. The success of this project influenced government policy and the design of oral health improvement programmes for children.

When Robin retired from The Dental Health Unit in 2007, he was appointed Director of the National Fluoride Information Service and continued to be a favourite international speaker, and a regular lecturer at the Salford PCD School. In fact, he never really retired as his advice and practical research wisdom was constantly in demand and he co-edited a book on gingival diseases in 2011. His enduring legacy will be in the thoughts of generations of Manchester and Bristol graduates who will remember his impish grin and the passion he could inspire in young students to really enjoy learning.

He is survived by his wife Gill, three daughters, two sons and ten grandchildren. Anthony Blinkhorn

\section{BRIAN HOLMES}

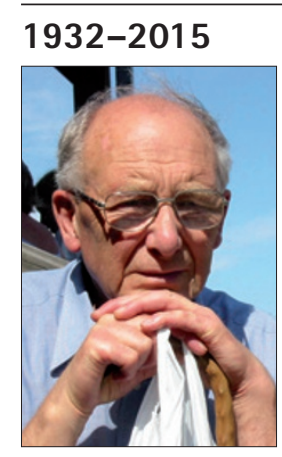

Brian Holmes died peacefully on 24 March 2015 after stoically enduring Parkinsonism in his later years.

Brian was born in Alvaston, Derby, where his father owned a successful butcher's business. He went to Bemrose School in Derby, before studying dentistry at Guy's Hospital, London, qualifying BDS in 1955. As a student, Brian played tennis, was a runner and a very useful fast bowler. National Service followed, when he was posted to Hildesheim (West Germany) where he first met Mary, a teacher with the British Armed Forces. They married in 1958.
After National Service, Brian worked in the school dental service in London. He spent his registrar years at the Charles Clifford Dental Hospital in Sheffield and then, with his friend and colleague John Muir, shared a senior registrar rotation between Bournemouth and the Royal Dental Hospital. In 1969, he was appointed consultant orthodontist to a large area in North Lincolnshire - initially covering Grimsby, Scunthorpe and Louth.

Brian was a man of strong principles and integrity, utterly committed to the NHS and to service to his patients. With long waits to see him, he declined to cancel his clinic when Princess Diana visited Grimsby in 1983 to open the new district hospital. Quietly unassuming and never seeking publicity, Brian's aim was to 'get the job done'.

He understood and completely empathised with the problems of his colleagues in general dental practice, which earned him their widespread respect. Many were very grateful for the experience gained as clinical assistants in his department, where they appreciated not only his understated (and often quirky) sense of humour, but also his very real and lasting enthusiasm for orthodontics. Brian was immensely touched by the large number of his colleagues - past and present - who attended his retirement 'do' in Grimsby in 1997. He continued to support his successor by working as an unpaid, honorary consultant for another ten years.

All this is more remarkable because, at home, he cared for Mary, who suffered early onset dementia from 1982 until her death in 1996. He had a strong Christian faith and studied scripture deeply. He was sometime church warden and church organist in the village outside Grimsby, where he lived for 45 years.

Brian was a keen gardener and a lifelong supporter of Derby County and Derbyshire County Cricket. He leaves two children: Stephen (a GP) and Elizabeth, and two grandchildren.

Stephen Dixon, John Muir, Elizabeth Collins and Stephen Holmes 